\title{
Effect of $\beta$-carotene-rich tomato lycopene $\beta$-cyclase $($ tlcy-b) on cell growth inhibition in HT-29 colon adenocarcinoma cells
}

\author{
Paola Palozza $^{1}$, Diana Bellovino ${ }^{2 *}$, Rossella Simone ${ }^{1}$, Alma Boninsegna ${ }^{1}$, Francesco Cellini ${ }^{3}$, \\ Giovanni Monastra ${ }^{2}$ and Sancia Gaetani ${ }^{2}$ \\ ${ }^{1}$ Institute of General Pathology, Catholic University School of Medicine, largo F. Vito, Roma, Italy \\ ${ }^{2}$ National Research Institute on Food and Nutrition, via Ardeatina 546, Roma, Italy \\ ${ }^{3}$ Metapontum Agrobios, Metaponto (MT), Italy
}

(Received 5 August 2008 - Revised 31 October 2008 - Accepted 31 October 2008 - First published online 24 December 2008)

Lycopene $\beta$-cyclase $(t l c y-b)$ tomatoes, obtained by modulating carotenogenesis via genetic engineering, contain a large amount of $\beta$-carotene, as clearly visible by their intense orange colour. In the present study we have subjected $t l c y-b$ tomatoes to an in vitro simulated digestion and analysed the effects of digestate on cell proliferation. To this aim we used HT-29 human colon adenocarcinoma cells, grown in monolayers, as a model. Digested tomatoes were diluted $(20 \mathrm{ml}, 50 \mathrm{ml}$ and $100 \mathrm{ml} / \mathrm{l})$ in culture medium and added to the cells for different incubation times $(24 \mathrm{~h}, 48 \mathrm{~h}$ and $72 \mathrm{~h}$ ). Inhibition of cell growth by tomato digestate was dose-dependent and resulted from an arrest of cell cycle progression at the G0/G1 and G2/M phase and by apoptosis induction. A down-regulation of cyclin D1, Bcl-2 and Bcl-xl expression was observed. We also found that heat treatment of samples before digestion enhanced $\beta$-carotene release and therefore cell growth inhibition. To induce with purified $\beta$-carotene solubilised in tetrahydrofuran the same cell growth inhibition obtained with the tomato digestate, a higher amount of the carotenoid was necessary, suggesting that $\beta$-carotene micellarised during digestion is utilised more efficiently by the cells, but also that other tomato molecules, reasonably made available during digestion, may be present and cooperate with $\beta$-carotene in promoting cell growth arrest.

$\beta$-Carotene-rich tomatoes: In vitro digestion: HT-29 cells: Cell cycle: Apoptosis

Retinol (vitamin $\mathrm{A}_{1}$ ) and its metabolites are essential in a wide range of physiological regulatory processes ${ }^{(1)}$. At the molecular and cellular level, this regulation involves the control of cell proliferation and differentiation through retinoid-dependent effects on gene expression ${ }^{(2)}$. Vitamin A deficiency is still a public health problem worldwide ${ }^{(3,4)}$. Since animals are not able to synthesise retinoids de novo, they must derive them from dietary vitamin $\mathrm{A}$ and provitamin A carotenoids. $\beta$-Carotene is the most potent precursor of vitamin A, and therefore efforts to manipulate the genetic background of plants widely used as food to produce $\beta$-carotene have received considerable attention ${ }^{(5-7)}$. Tomato fruit is characterised by the high content of lycopene that, although not a vitamin A precursor, can be readily cyclised to $\beta$-carotene by the plant enzyme lycopene $\beta$-cyclase. Some authors ${ }^{(8)}$ have succeeded in modulating the carotenogenesis in tomato fruit to induce accumulation of $\beta$-carotene. Tomato plants were transformed with tomato lycopene $\beta$-cyclase $($ tlcy-b) cDNA under the control of cauliflower mosaic virus $35 \mathrm{~S}$ promoter, and acquired the ability of converting almost all lycopene contained in the fruits into $\beta$-carotene. $\beta$-Carotene is not only a vitamin A precursor, but performs in animals other functions related to its chemical structure, mainly acting as an antioxidant $^{(9,10)}$. The consumption of a diet rich in fruit and vegetables, and therefore in carotenoids, has been associated with a decreased risk of certain types of cancer and cardiovascular disease ${ }^{(11,12)}$. Moreover, tomatoes contain not only lycopene, but also other carotenoids, vitamins and other molecules that, possibly in combination, can contribute to their positive effects on health.

Human intestinal cells cultured in vitro represent very useful models to study the effects of carotenoids on the barrier between the external world and the inside of the human organism $^{(13)}$. In a previous study ${ }^{(14)}$ we utilised an in vitro model consisting of the adenocarcinoma colon cells HT-29 and HCT-116, that still exhibit several morphological and biochemical characteristics of intestinal cells and that accumulate carotenoids, to investigate the potential mechanisms underlying the anti-tumoural effects of tomatoes reported in the literature ${ }^{(15,16)}$. In order to deliver tomatoes to cells in culture, an in vitro digestion procedure mimicking the physiological in vivo function has been adapted and utilised $^{(17)}$. The resulting digestate was then added to the cell cultures at different concentrations and for various lengths of times.

The aim of the study reported in the present paper was to utilise HT-29 human colon adenocarcinoma cells cultured in monolayers to investigate the effects of the $\beta$-carotene-rich

Abbreviations: $t l c y$ - $b$, tomato lycopene $\beta$-cyclase; TUNEL, terminal deoxynucleotidyl transferase-mediated dUTP nick end labelling.

* Corresponding author: Dr Diana Bellovino, fax +3906 51494550, email bellovino@inran.it 
tomato $t l c y-b$ digestates on cell growth and on the expression of genes that regulate the cell cycle and apoptosis, in order to understand the molecular mechanisms that govern cell growth inhibition by $\beta$-carotene liberated during digestion together with other molecules from the food matrix represented by the $\beta$-carotene-rich $t l c y-b$ tomato.

The results reported demonstrate that the molecules liberated from digested tlcy-b tomatoes by in vitro simulated digestion inhibit the growth of HT-29 colon cancer cells by interfering with cell cycle progression and apoptosis, in particular by modulating the expression of some key regulator proteins. To induce the same rate of cell growth inhibition with purified $\beta$-carotene solubilised in tetrahydrofuran, HT-29 cells must be treated with a higher amount of $\beta$-carotene; it is therefore evident that $\beta$-carotene provided as tlcy-b digestate is more active in the antiproliferative action on HT-29 cells than purified $\beta$-carotene, either for the efficient micellarisation that takes place during digestion, and for the presence and cooperation of other molecules $^{(18)}$.

\section{Materials and methods}

\section{Preparation of tomato samples and in vitro simulated} digestion

The GM tlcy-b tomato was obtained by transformation of the Red Setter tomato with Agrobacterium tumefaciens, harbouring the tomato lycopene $\beta$-cyclase $(t l c y-b)$ cDNA, under the control of cauliflower mosaic virus $35 \mathrm{~S}$ promoter. The transgenic tomato fruits acquired the ability to convert almost all lycopene into $\beta$-carotene, and to increase the total carotenoid content $^{(8)}$. To prepare samples, tlcy-b frozen tomatoes were chopped and homogenised with a B-400 Buchi mixer (Buchi Labortechnik AG, Flawil, Switzerland).

All manipulations with tomato samples were performed under subdued lighting and in amber glass bottles to minimise the destruction of carotenoids. Samples of $1 \mathrm{~g}$ homogenised tomato were mixed with $1.8 \mathrm{ml}$ saline $(140 \mathrm{~mm}-\mathrm{NaCl}, 5 \mathrm{~mm}-$ $\mathrm{KCl}, 150 \mu \mathrm{M}$-butylated hydroxytoluene in tetrahydrofuran), and then hand-homogenised in a Teflon/glass Potter homogeniser. In vitro simulated digestion was performed according to Garrett et al. ${ }^{(17)}$ with modifications. Briefly, after homogenisation, samples were acidified to $\mathrm{pH} 2.0$ with $1 \mathrm{M}-\mathrm{HCl}$ before the addition of $50 \mu \mathrm{l}$ of pepsin, from porcine stomach mucosa $(0.2 \mathrm{~g}$ pepsin in $5 \mathrm{ml}$ of $0.1 \mathrm{M}-\mathrm{HCl})$, and samples were incubated in a shaking water-bath for $60 \mathrm{~min}$ at $37^{\circ} \mathrm{C}$. After gastric digestion, the $\mathrm{pH}$ was raised to 6.9 with $1 \mathrm{M}-\mathrm{NaHCO}_{3}$. Intestinal digestion was simulated by the addition of $200 \mu \mathrm{l}$ of pancreatin-bile solution from porcine pancreas $(0.45 \mathrm{~g}$ porcine bile extract and $0.075 \mathrm{~g}$ pancreatin in $37.5 \mathrm{ml}$ of $0.1 \mathrm{M}-\mathrm{NaHCO}_{3}$ ) and incubated in a shaking water-bath at $37^{\circ} \mathrm{C}$ for $120 \mathrm{~min}$. The $\mathrm{pH}$ of the samples was then adjusted to 7.5. A sample of homogenate was subjected to heat treatment before gastric digestion by boiling for $15 \mathrm{~min}$ in a water-bath.

At the end of the digestion procedure, samples were centrifuged at $12000 \mathrm{rpm}$ for $30 \mathrm{~min}$ at $4^{\circ} \mathrm{C}$ in a Sorvall SS-34 angle rotor, and the supernatant fractions were collected and stored at $-80^{\circ} \mathrm{C}$.

\section{Cell culture}

HT-29 human colon adenocarcinoma cells (American Type Culture Collection (ATCC), Rockville, MD, USA) were grown in minimum essential medium. Cells were maintained in log phase by seeding them twice per week at the density of $3 \times 10^{5}$ cells $/ \mathrm{ml}$ at $37^{\circ} \mathrm{C}$ under a $5 \% \mathrm{CO}_{2}$-air atmosphere. The medium was supplemented with $10 \%(\mathrm{v} / \mathrm{v})$ fetal calf serum (Flow, Irvine, North Ayrshire, UK) and $2 \mathrm{~mm}$-glutamine and was not further replaced throughout the experiment. Experiments were routinely carried out on triplicate cultures. After the incubation, cells were harvested and quadruplicate haemocytometer counts were performed. The trypan blue dye exclusion method was used to evaluate the percentage of viable cells.

The Caco- 2 cell line was obtained from the ATCC. The cells were grown and maintained in Dulbecco's modified Eagle's medium (DMEM) without pyruvate, containing 25 mM-glucose and $\mathrm{NaHCO}_{3}$ (3.7 g/l) (DMEM; Biochrom, $\mathrm{KG}$, Berlin, Germany), supplemented with $4 \mathrm{~mm}$ L-glutamine (Euroclone, Wetherby, West Yorks, UK) and $1 \%$ non-essential amino acids (Euroclone). Cells were left to differentiate for $15 \mathrm{~d}$ after confluence. Differentiated Caco-2 cells were incubated for $24 \mathrm{~h}$ in the presence or in the absence of $t c l y-b$ tomato digestate $(100 \mathrm{ml} / \mathrm{l})$. Cells were then removed from the dishes, stained by trypan blue and counted under a microscope for viable and dead cells.

\section{Cell growth-inhibition assay}

Tomato digestates were serially diluted in cell culture medium as reported in the figure legends. Cells were seeded in twentyfour-well plates with $3 \times 10^{4}$ cells/well and maintained for $24 \mathrm{~h}$ before any treatment to facilitate their adhesion on the well. The control group consisted of cells treated with the same amount of digestion mixture, for example, proteolytic and lypolytic enzymes without tomato, diluted with culture medium and of cells without any treatment. Since no differences in terms of viability, cell cycle, caspase activity and cell cycle-related proteins were found between the two control groups, control cells are referred to cells without any treatment. At the time indicated, cells were removed from the wells, stained with trypan blue and counted under a microscope for viable and dead cells.

\section{Cell cycle analysis}

Cell cycle distribution was analysed by flow cytometry, as previously described ${ }^{(19)}$. Samples of $10^{6}$ cells were harvested by centrifugation, washed in PBS and fixed with ice-cold $70 \%$ ethanol. The cells were incubated at $4^{\circ} \mathrm{C}$ for $30 \mathrm{~min}$ and then centrifuged at $2500 \mathrm{~g}$ for $10 \mathrm{~min}$. The pellet was resuspended in $0.5 \mathrm{ml}$ PBS and $0.5 \mathrm{ml}$ DNA-Prep stain (Coulter Reagents, Miami, FL, USA), containing RNAse ( $1 \mathrm{~g} / \mathrm{l})$ and propidium iodide $(50 \mathrm{~g} / \mathrm{l})$. All samples were incubated for $30 \mathrm{~min}$ in the dark at $4^{\circ} \mathrm{C}$. The DNA content of cells stained with propidium iodide was measured with a FACS instrument (EPICS XL-MCL Flow Cytometer; Coulter Electronics, Miami, FL, USA), by using Multicycle AV software (Phoenix Flow Systems, San Diego, CA, USA). 
Apoptosis detection by the terminal deoxynucleotidyl transferase-mediated dUTP nick end labelling method

The percentage of apoptotic cells was determined by terminal deoxynucleotidyl transferase-mediated dUTP nick end labelling (TUNEL). Briefly, cells were centrifuged, fixed with acetone, and incubated for $5 \mathrm{~min}$ with the hybridisation buffer (Boehringer-Mannheim, Germany). Then 2.5 units of terminal deoxynucleotidyltransferase (Tdt) and $100 \mathrm{pmol}$ biotin-dUTP in hybridisation buffer were added and incubated for $1 \mathrm{~h}$ at $37^{\circ} \mathrm{C}$. Thereafter, cells were incubated with streptavidin-biotin-peroxidase complex for $30 \mathrm{~min}$ at room temperature. The sites of peroxidase binding were detected with diaminobenzidine. The percentage of TUNEL-positive apoptotic cells (labelling index, LI \%) was counted at $\times 400$ magnification. In the absence of Tdt, no unspecific staining was observed. For each slide, three randomly selected microscopic fields were observed and at least 100 cells per field were evaluated.

\section{Caspase-3 activity assay}

The extent of apoptosis was also measured by the caspase- 3 activity assay as previously described ${ }^{(20)}$. Briefly, after a $24 \mathrm{~h}$ treatment, cells $\left(2 \times 10^{6}\right)$ were lysed in $50 \mathrm{mM}$-2-amino2-hydroxymethyl-propane-1,3-diol- $\mathrm{HCl}$ buffer (pH 7.5) containing $0.5 \mathrm{~mm}-\mathrm{EDTA}, \quad 0.5 \%$ IGEPAL $^{\circledR} \mathrm{Ca}-630$ and $150 \mathrm{~mm}-\mathrm{NaCl}$. Then the cell lysate was incubated with $50 \mu \mathrm{M}$-fluorogenic substrate, N-acetyl-Asp-Glu-ValAsp-(7-amino-4-methylcoumarine) (Ac-DEVD-AMC; Alexis Biochemicals, San Diego, CA, USA), in a reaction buffer (10 mM-HEPES (pH 7.5) containing $50 \mathrm{~mm}-\mathrm{NaCl}$ and $2.5 \mathrm{~mm}$-dithiothreitol) for $120 \mathrm{~min}$ at $37^{\circ} \mathrm{C}$. The release of AMC was measured with excitation at $380 \mathrm{~nm}$ and emission at $460 \mathrm{~nm}$ using a fluorescence spectrophotometer.

\section{Western blot analysis}

Cells $\left(10 \times 10^{6}\right)$ were harvested, washed once with ice-cold PBS and gently lysed for $30 \mathrm{~min}$ in ice-cold lysis buffer

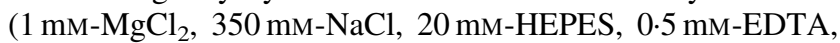
$0 \cdot 1 \mathrm{~mm}$-ethylene glycol tetra-acetic acid, $1 \mathrm{mM}$-dithiothreitol, $1 \mathrm{mM}-\mathrm{Na}_{4} \mathrm{P}_{2} \mathrm{O}_{7}, 1 \mathrm{~mm}$-phenylmethanesulfonyl fluoride, $1 \mathrm{~mm}-$ aprotinin, $1.5 \mathrm{~mm}$-leupeptin, $1 \mathrm{mM}-\mathrm{Na}_{3} \mathrm{VO}_{4}, 20 \%$ glycerol, $1 \% \mathrm{NP} 40)$. Cell lysates were centrifuged for $10 \mathrm{~min}$ at $4^{\circ} \mathrm{C}$ $(10000 \mathrm{~g})$ and the supernatant fractions were used for Western Blot analysis. The anti-cyclin D1 (clone 72-13G; catalogue no. SC-450), anti-p21 WAF-1/CIP-1 (clone F-5; catalogue no. 6246), anti-p27 (clone N-20; catalogue no. SC-527), anti-Bax (clone P-19; catalogue no. SC-526), anti-Bcl-xl S/l (clone L-19; catalogue no. SC-1041) and anti-p53 (clone DO-1; catalogue no. SC-126) monoclonal antibodies were purchased from Santa Cruz Biotechnology (Santa Cruz, CA, USA). The anti-Bcl-2 (clone: Bcl-2/100/D5) monoclonal antibody was purchased from YLEM (Rome, Italy). Blots were washed with PBS and exposed to horseradish peroxidaselabelled secondary antibodies (Amersham Pharmacia Biotech, Arlington Heights, IL, USA) for $45 \mathrm{~min}$ at room temperature. Immunocomplexes were visualised by the enhanced chemiluminescence detection system $\left(\mathrm{ECL}^{\mathrm{TM}}\right.$ Western Blotting
Analysis System; ECL, Amersham, Bucks, UK) and quantified by densitometric scanning.

\section{$\beta$-Carotene extraction and assay}

$\beta$-Carotene was extracted with 1 volume of methanol and 3 volumes of hexane-diethyl ether $(1: 1)$ from $10 \times 10^{6}$ cells after the different times of treatment and analysed by HPLC, as described previously ${ }^{(21)}$.

Samples were dissolved in methanol and a $20 \mu \mathrm{l}$ sample was analysed by reverse-phase HPLC with spectrophotometric detection on a Perkin-Elmer LC-295 detector at $450 \mathrm{~nm}$. The column was packed with Alltech C18 Adsorbosphere HS material, $3 \mu \mathrm{m}$ particle size, in a $15 \times 0.46 \mathrm{~cm}$ cartridge format (Alltech Associates, Deerfield, IL, USA). A $1 \mathrm{~cm}$ cartridge precolumn, containing $5 \mu \mathrm{m} \mathrm{C} 18$ Adsorbosphere packing was used. Analyses were done by gradient elution; the initial mobile phase was $85 \%$ acetonitrile $-15 \%$ methanol, with the addition of $30 \%$ 2-propanol at $8 \mathrm{~min}$. Ammonium acetate (HPLC grade, $0.01 \%$ ) was added to the initial mobile phase.

\section{Statistical analysis}

Three separate cultures per treatment were utilised for analysis in each experiment. Values are presented as mean values with their standard errors. One-way ANOVA was adopted to assess differences among the concentrations. When significant values were found $(P<0 \cdot 05)$, post hoc comparisons of means were made using Fisher's test. Differences were analysed using Minitab Software (Minitab, Inc., State College, PA, USA). Multifactorial two-way ANOVA was adopted to assess any differences among the treatments and the times (Fig. 1(B), Fig. 6). When significant values were found $(P<0.05)$, post hoc comparisons of means were made using the honestly significant differences test.

\section{Results}

The amount of $\beta$-carotene transferred to the aqueous fraction during the digestion procedure (8.7 (SEM 0.8) $\mu \mathrm{g} / \mathrm{g}$ fresh weight) was less than one tenth of the amount of $\beta$-carotene originally contained in the homogenate (140.0 (SEM 14.5) $\mu \mathrm{g} / \mathrm{g}$ fresh weight). Moreover, heat treatment of tomato homogenate before in vitro digestion induced, as demonstrated also in other studies ${ }^{(21)}$, a three-fold increase in the carotenoid content, reaching the value of 22.0 (SEM $0 \cdot 3$ ) $\mu \mathrm{g} / \mathrm{g}$ fresh weight. This is in agreement with other findings according to which processing of vegetable foods before consumption enhances to a lesser or greater extent - depending on treatment and on carotenoid type - carotenoid release ${ }^{(22)}$.

Fig. 1 shows the effects of $t c l y-b$ tomato digestate on the growth of HT-29 cells, as measured by direct cell counting. Fig. 1(A) shows the effects of varying digestate concentrations in cells treated for $24 \mathrm{~h}$ and Fig. 1(B) shows the effects of $100 \mathrm{ml} / \mathrm{l}$ digestate in cells treated for different periods of time. $t c l y-b$ Tomato digestate inhibited the growth of HT-29 cells in a dose-dependent manner. After $24 \mathrm{~h}$ of incubation, a cell growth inhibition of about 10,25 and $55 \%$ was observed following the addition of $t c l y-b$ tomato digestate to the culture medium at the concentrations of 20,50 and 

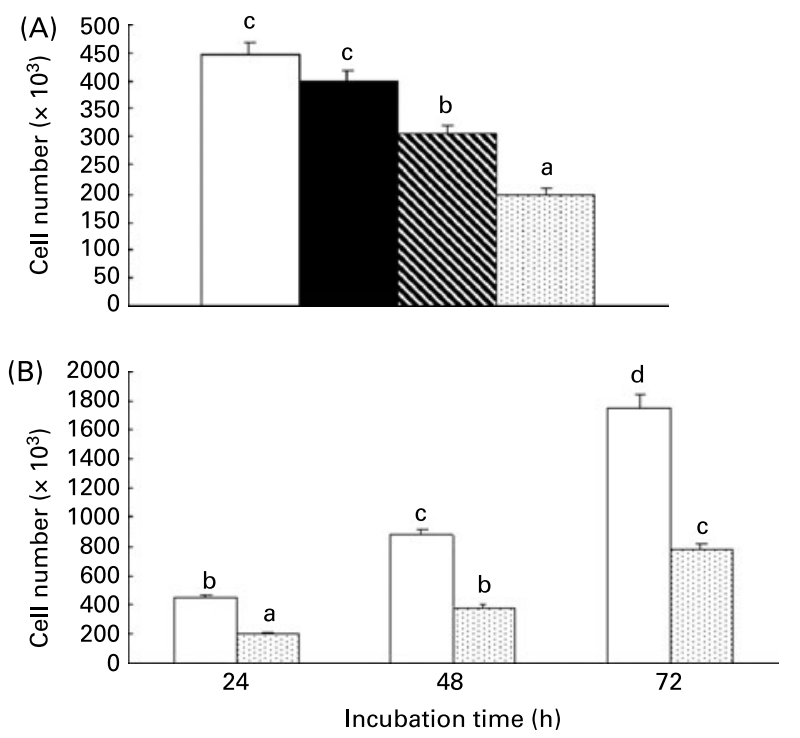

Fig. 1. Effects of tomato lycopene $\beta$-cyclase $(t c l y-b)$ tomato digestate on the growth of HT-29 cells. (A) Effects of different digestate concentrations for

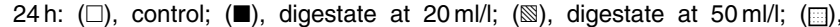
digestate at $100 \mathrm{ml} / \mathrm{l}$. Values are the means of three different experiments, with standard errors represented by vertical bars. ${ }^{a, b, c}$ Mean values with unlike letters were significantly different $(P<0.05$; Fischer's test). (B) Effects

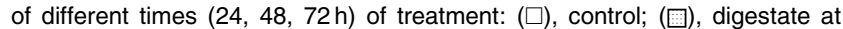
$100 \mathrm{ml} / \mathrm{l}$. Values are the means of three different experiments, with standard errors represented by vertical bars. ${ }^{a, b, c, d}$ Mean values with unlike letters were significantly different $(P<0.002$; Tukey's test). The treatment-time interaction was significant $(P<0.05)$.

$100 \mathrm{ml} / \mathrm{l}$, respectively (Fig. 1(A)). A clear inhibition of cell growth was evidenced after $24 \mathrm{~h}$ of incubation following the addition of digestate at the concentration of $100 \mathrm{ml} / \mathrm{l}$, which was not significantly modified prolonging the incubation time until $72 \mathrm{~h}$ (Fig. 1(B)). The effect seems to be specific for tumour cells, since differentiated Caco-2 cells ${ }^{(23)}$ were not affected in cell viability by $t c l y-b$ tomato digestate at the concentration of $100 \mathrm{ml} / \mathrm{l}$ for $24 \mathrm{~h}$. Cell viability was 96 (SEM 6) and 97 (SEM 6) \% in the absence and in the presence of digestate, respectively.

Since it has been previously reported that carotenoids act as strong apoptotic inducers in tumour cells, we examined whether the reduction in cell number was associated with apoptosis induction.

Apoptosis induction by $t c l y-b$ tomato digestate was studied by analysing the percentage of TUNEL-positive cells (Fig. 2(A)) and the activation of caspase-3, one of the most important cell death executioners for apoptosis (Fig. 2(B)). We found that a $24 \mathrm{~h}$ treatment with the digestate resulted in both an increase in the percentage of TUNEL-positive cells and in a strong dose-dependent increase in 7-amido-4-methylcoumarin fluorescence, indicative of the activation of caspase3 in HT-29 cells.

Consistent with these results, analysis of the cell cycle revealed the appearance of a pre-G1 peak (subdiploid DNA content), which is characteristic of apoptotic cell death, in HT-29 cells treated with tcly- $b$ tomato digestate for $24 \mathrm{~h}$ (Table 1). This value increased in a dose-dependent manner. Moreover, treatment with $t c l y-b$ tomato digestate for $24 \mathrm{~h}$ resulted in a significant dose-dependent inhibition of cell

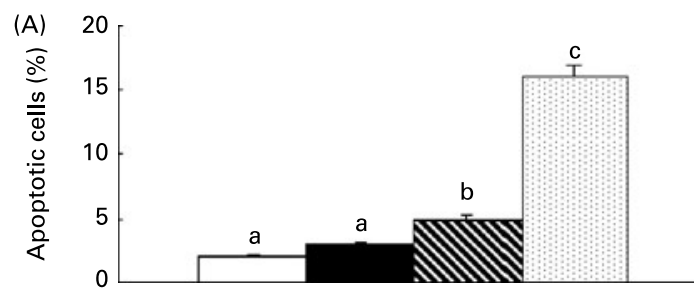

(B)

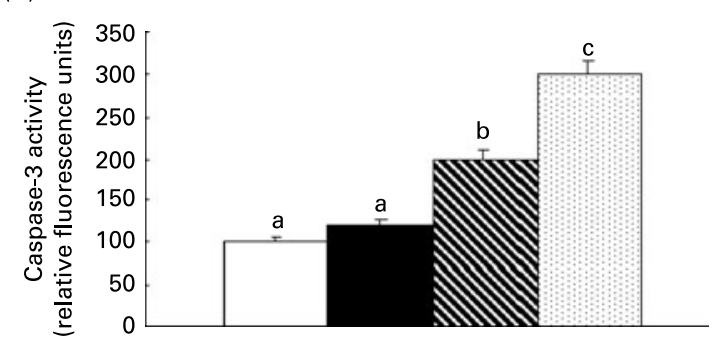

Fig. 2. Effects of varying tomato lycopene $\beta$-cyclase $(t c l y-b)$ tomato digestate concentration on apoptosis induction in HT-29 cells: $(\square)$, control; ( $\square$ ), diges-

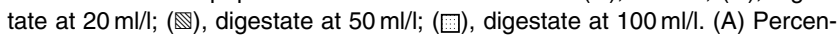
tage of terminal deoxynucleotidyl transferase-mediated dUTP nick end labelling (TUNEL)-positive cells. (B) Caspase-3 activation. Cells were treated for $24 \mathrm{~h}$. Values are the means of three different experiments, with standard errors represented by vertical bars. ${ }^{a, b, c}$ Mean values with unlike letters were significantly different $(P<0.05$; Fischer's test).

cycle progression, showed by the accumulation of cells in both the G0/G1 and G2/M phase and by a concomitant decrease in the percentage of cells in the $\mathrm{S}$ phase.

To explore the effects of $t c l y-b$ tomato digestate on apoptosis-regulating proteins, we examined the expression of Bcl-2 and Bcl-xl, which are known to suppress programmed cell death, and that of Bax, which promotes it, in HT-29 cells treated for $24 \mathrm{~h}$ (Fig. 3). Treatment with tomato digestate significantly reduced the expression of both Bcl-2 and Bcl-xl in a dose-dependent manner. In contrast, no significant changes in the expression of Bax were found under the same conditions.

Fig. 4 shows the effect of increasing $\beta$-carotene concentrations on cell growth (Fig. 4(A)), caspase-3 activation (Fig. 4(B)), and Bcl-2 (Fig. 4(C)) and Bcl-xl (Fig. 4(D)) content following a $24 \mathrm{~h}$ treatment. Carotenoid treatment inhibited cell growth and induced caspase- 3 activation in a dose-dependent manner. Such effects were also accompanied by a decreased $\mathrm{Bcl}-2$ :actin and $\mathrm{Bcl}-\mathrm{xl}$ :actin ratio.

When the activity of $t c l y$ - $b$ tomato digestate, containing in our experimental conditions $\beta$-carotene at the concentrations of $0.08,0.16$ and $0.8 \mu \mathrm{M}$ corresponding to 20,50 and $100 \mathrm{ml} / \mathrm{l}$, respectively, was compared with that of purified $\beta$ carotene at concentrations ranging from 0.5 to $10 \mu \mathrm{M}$ (Fig. 5), the growth-inhibitory effect of the digestate was remarkably higher than that of the purified $\beta$-carotene, as highlighted by the different percentage of cell growth inhibition.

As shown in Fig. 6, HT-29 cells incorporated and/or associated $\beta$-carotene linearly. A time-dependent linear increase in $\beta$-carotene content was observed in cells treated for $24 \mathrm{~h}$ with both $100 \mathrm{ml} / \mathrm{l}$ digestate and purified $\beta$-carotene at the concentration of $0.8 \mu \mathrm{M}$, which corresponds to the digestate 
Table 1. Effect of tomato lycopene $\beta$-cyclase $(t / c y-b)$ tomato digestate on cell cycle distribution in HT-29 cells (\%)

(Mean values of three different experiments with their standard errors)

\begin{tabular}{|c|c|c|c|c|c|c|c|c|}
\hline \multirow{2}{*}{$\begin{array}{l}\text { Phase... } \\
\text { Treatment }\end{array}$} & \multicolumn{2}{|c|}{ G0/G1 } & \multicolumn{2}{|c|}{$S$} & \multicolumn{2}{|c|}{ G2/M } & \multicolumn{2}{|c|}{ Sub-G1 } \\
\hline & Mean & SEM & Mean & SEM & Mean & SEM & Mean & SEM \\
\hline Control & $47 \cdot 0^{a}$ & 3.0 & $41.0^{c}$ & 2.9 & $10 \cdot 0^{c}$ & $1 \cdot 1$ & $2 \cdot 0^{a}$ & 0.2 \\
\hline $\mathrm{T}(20 \mathrm{ml} / \mathrm{l})$ & $47 \cdot 8^{\mathrm{a}}$ & $2 \cdot 9$ & $39.5^{\mathrm{c}}$ & $3 \cdot 0$ & $10 \cdot 7^{\mathrm{C}}$ & 1.0 & $2 \cdot 0^{\mathrm{a}}$ & 0.2 \\
\hline $\mathrm{T}(50 \mathrm{ml} / \mathrm{l})$ & $53 \cdot 3^{\mathrm{b}}$ & 3.5 & $27 \cdot 8^{\mathrm{b}}$ & 3.0 & $12 \cdot 0^{\mathrm{b}}$ & 0.5 & $6.9^{b}$ & 0.4 \\
\hline $\mathrm{T}(100 \mathrm{ml} / \mathrm{l})$ & $58 \cdot 5^{\mathrm{C}}$ & 4.2 & $15 \cdot 3^{a}$ & $2 \cdot 5$ & $16 \cdot 0^{\mathrm{a}}$ & 0.4 & $10 \cdot 2^{c}$ & 0.7 \\
\hline
\end{tabular}

Control, vehicle control-treated cells; $T, t / c y-b$ tomato digestate-treated cells.

a,b,c Mean values within a column with unlike superscript letters were significantly different $(P<0.05$; Fisher's test).

carotenoid amount. Purified $\beta$-carotene was incorporated and/ or associated to a greater extent than $\beta$-carotene in the digestate. The cellular carotenoid amount increased in a dosedependent manner after the addition of 20, 50 and $100 \mathrm{ml} / \mathrm{l}$ digestate, respectively, for $24 \mathrm{~h}$ (data not shown).

\section{Discussion}

In the present study we investigated the growth-inhibitory effect of the $\beta$-carotene-rich $t l c y-b$ tomato, obtained by the modulation of carotenogenesis in tomato fruits via genetic engineering $^{(8)}$, on human intestinal cancer cells cultured in vitro. Colon cancer is one of the most common causes of death in Western populations ${ }^{(24)}$; epidemiological and experimental data have shown that a high dietary intake of fruit and vegetables rich in carotenoids is associated with a lower risk of colon neoplasia ${ }^{(25-27)}$. Although some human intervention trials failed to demonstrate the prevention of colon cancer by $\beta$-carotene supplements ${ }^{(28-30)}$, other interventions showed a significant protective effect of $\beta$-carotene ${ }^{(31)}$, a reduced rate of colon cell proliferation in patients with adenomatous polyps $^{(32)}$ and protective effects against colon carcinogenesis in animal models ${ }^{(33,34)}$. More recently, growth-inhibitory
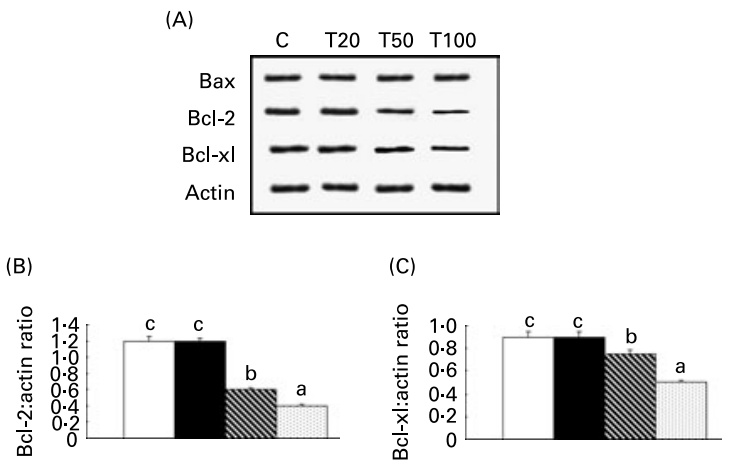

Fig. 3. Bax, $\mathrm{Bcl}-2$ and $\mathrm{Bcl}-\mathrm{xl}$ expression in HT-29 cells treated with varying tomato lycopene $\beta$-cyclase $(t c l y-b)$ tomato digestate concentrations for $24 \mathrm{~h}$ :

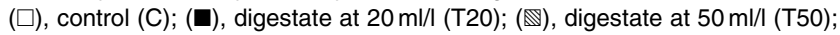

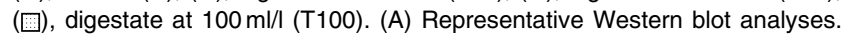
(B) $\mathrm{Bcl}-2$ densitometric analysis. (C) Bcl-xl densitometric analysis. Values are the means of three different determinations, with standard errors represented by vertical bars. ${ }^{a, b, c}$ Mean values with unlike letters were significantly different $(P<0.05$; Fischer's test). effects by carotenoids in human colon cancer cell lines were also reported by our group ${ }^{(35,36)}$.

The model system utilised in the present study consisted of HT-29 human adenocarcinoma colon cells treated with different amount of $t l c y$ - $b$ tomato subjected to an in vitro simulated digestion $^{(17)}$. During the in vitro digestion, thanks to the action of pancreatic enzymes and bile salts, at specific $\mathrm{pH}$ conditions, bioactive molecules are transferred from the food matrix to the aqueous micellar fraction, becoming available for cell uptake. In vitro simulated digestion has been proven to represent a very useful and efficient approach to deliver molecules to cells in culture, quite similar to the physiological process that takes place in vivo in the gastrointestinal tract. This method has been utilised for assessing bioaccessibility and bioavailability of $\mathrm{Fe}^{(37)}$, amino acids ${ }^{(38)}$, carotenoids from baby food meals $^{(17)}$ and of other molecules. It has also been recently applied by us ${ }^{(14)}$ to the study of the effects of tomato lycopene on the growth of colon cancer cells. We have shown that ripe tomato, containing essentially lycopene, is a anti-proliferative agent not only in prostate cancer cells ${ }^{(39)}$, but also in colon cancer cells such as HT-29. In fact, tomato digestate inhibited cell cycle progression through the decrease of cyclin D1 expression and induced apoptosis through the modulation of Bcl-2 and Bcl-xl proteins. This effect seems to be specific for colon cancer cells since, as it has been reported in the Results section, differentiated Caco- 2 cells, representing a suitable model of absorbing intestinal cells ${ }^{(23)}$, are not affected in their viability by digestate in the range of concentrations used in the present study. This observation is in agreement with previous findings, comparing the effects of $\beta$-carotene in normal and tumour cells ${ }^{(40)}$. In particular, in a previous study, we reported that $\beta$-carotene was much more potent in inhibiting the growth and altering the viability in undifferentiated than in dimethyl sulfoxide-differentiated HL-60 cells ${ }^{(41)}$.

Lycopene and $\beta$-carotene exert a significant antioxidant activity, but their anti-proliferative action, tested in different cell types, has been attributed also to other specific molecular processes to which these molecules take part ${ }^{(42)}$. For instance, it has been demonstrated in prostate cancer cells that lycopene regulates the expression of specific proteins, such as connexin 43 , involved in proper cell-cell communication and therefore in the control of cell proliferation ${ }^{(43)}$. $\beta$-Carotene is the main precursor of vitamin A, a well-characterised morphogen that, once metabolised to retinoic acid, modulates the expression of hundreds of genes involved in embryogenesis, cell growth and differentiation ${ }^{(44)}$. 
(A)

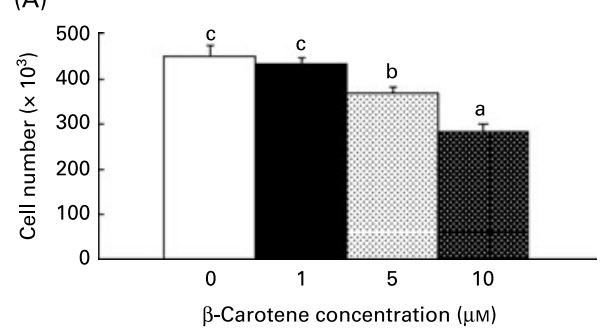

(B)

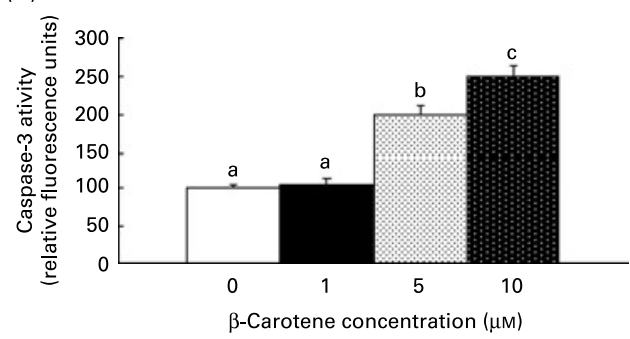

(C)

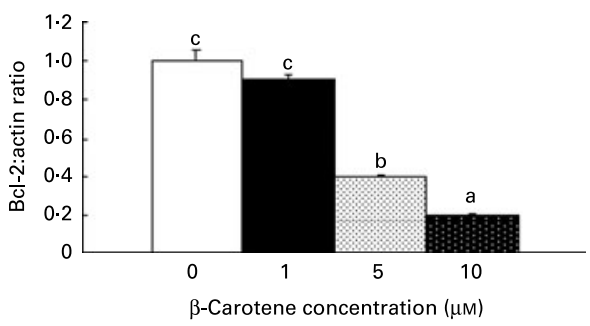

(D)

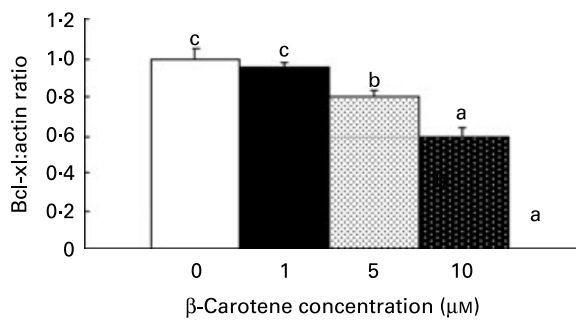

Fig. 4. Effect of $\beta$-carotene on cell growth (A), caspase-3 activation (B), Bcl-2 (C) and Bcl-xl (D) content in HT-29 cells following a $24 \mathrm{~h}$ treatment. Values are the means of three different experiments, with standard errors represented by vertical bars. ${ }^{\mathrm{a}, \mathrm{b}, \mathrm{c}}$ Mean values with unlike letters were significantly different $(P<0.05$; Fischer's test).

We have investigated in the present study the mechanisms involved in the growth-inhibitory effects of molecules, mainly $\beta$-carotene, released from the $t l c y-b$ tomato during the in vitro digestion treatment and probably presented to the cells in micelles ${ }^{(45)}$. Only a small amount of $\beta$-carotene, less than $10 \%$, is released during digestion; in agreement with the observation of other authors ${ }^{(46)}$, this amount increases more than three times when the tomato homogenate is subjected to heat treatment before digestion.

The mechanisms by which $\beta$-carotene inhibits the growth of colon cancer cells is still not completely understood. It was shown that apoptosis is involved, since this carotenoid interferes with cell cycle progression ${ }^{(20)}$. In the present paper we have investigated and elucidated in HT-29 human colon adenocarcinoma cells the effects of $t l c y-b$ tomato digestate on individual steps of the cell cycle and some key proteins involved in this activity.

Since it has been previously reported ${ }^{(41)}$ that carotenoids are strong apoptotic inducers in cancer cells, we investigated

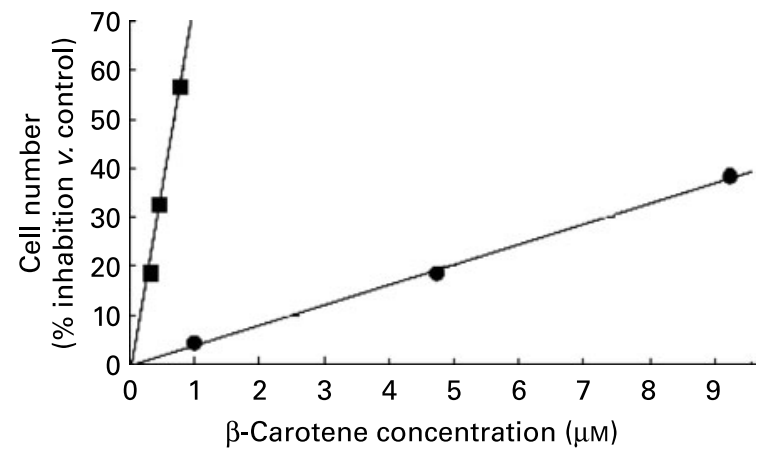

Fig. 5. Comparison of $\beta$-carotene $(\bullet)$ and tomato lycopene $\beta$-cyclase $(t c l y-b)$ tomato digestate $(\boldsymbol{\square})$ ability in inhibiting HT-29 cells growth after $24 \mathrm{~h}$ treatment. Concentrations of $t c l y-b$ tomato digestate of 20,50 and $100 \mathrm{ml} / \mathrm{l}$ correspond to $\beta$-carotene concentrations of $0.08,0.16$ and $0.8 \mu \mathrm{M}$, respectively. whether the inhibition of proliferation caused by digested $t l c y-b$ tomato was associated with induction of apoptosis. By both methods utilised, TUNEL-positive cells and activation of caspase- 3 , it was demonstrated that $t l c y-b$ tomato digestate indeed induced apoptosis. In parallel, the expression of Bcl-2 and Bcl-xl, inhibitors of programmed cell death, was decreased. On the other hand, the pro-apoptotic protein Bax was not affected by carotenoid treatment. It is well known that the ratio of the anti-apoptotic:pro-aopotic Bcl-2 family proteins, more than the level of the individual proteins, is extremely important in modulating the apoptotic process ${ }^{(47)}$. It has been demonstrated that $\beta$-carotene is able to decrease the expression of $\mathrm{Bcl}-2$ and $\mathrm{Bcl}-\mathrm{xl}$ in colon cancer cells $^{(20,48)}$ and to diminish that of Bcl-2 in HL-60 cells ${ }^{(41)}$. Such effects were strictly related to apoptosis induction and to reactive oxygen species production by the carotenoid. This finding is particularly interesting in the light of the data supporting a role for $\mathrm{Bcl}-2$ in an antioxidant pathway,

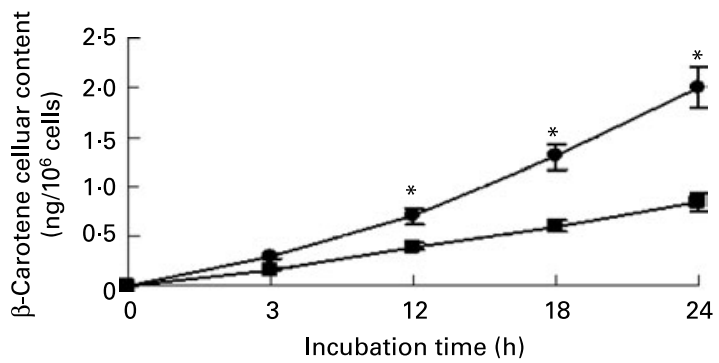

Fig. 6. $\beta$-Carotene incorporation and/or association in HT-29 cells treated with tomato lycopene $\beta$-cyclase $(t c l y-b)$ tomato digestate $(\boldsymbol{\square})$ and purified $\beta$-carotene $(\bullet)$ for $24 \mathrm{~h}$. The concentration of digestate in cultured medium was $100 \mathrm{ml} / \mathrm{l}$ and that of the purified carotenoid was $0.8 \mu \mathrm{M}$. Values are the means of three different experiments, with standard errors represented by vertical bars. *Mean value was significantly different from that of the digestate-treated cells $(P<0.005$; Tukey's test $)$. 
whereby this protein prevents programmed cell death by decreasing the formation of reactive oxygen species and lipid peroxidation products ${ }^{(49)}$.

In addition, data from other studies suggest that carotenoids modulate pro-apoptotic Bcl-2 family proteins, including $\mathrm{Bad}^{(50)}, \mathrm{Bid}^{(19)}$ and $\mathrm{Bax}^{(51)}$ in different experimental models. In particular, it has been recently shown that the increase in Bax expression and in apoptosis induction caused by cigarette tar was prevented by the addition of $\beta$-carotene in Rat- 1 fibroblasts as well as in different tumour cell lines ${ }^{(51)}$. On the other hand, an increased expression of Bax protein by $\beta$-carotene has been recently reported in U-937 cells and human umbilical vein endothelial cells by micro-array analysis ${ }^{(52,53)}$.

Since apoptosis is the end point of some epithelial colonic cell differentiation pathways, a process that induces apoptosis should also reduce proliferative signals. In fact, the inhibition of growth and the increased expression of Bcl-2 and Bcl-xl was associated with the slowdown of cell cycle progression at the $\mathrm{G} 0 / \mathrm{G} 1$ and $\mathrm{G} 2 / \mathrm{M}$ phase.

HT-29 cells accumulate $\beta$-carotene in a linear dose-dependent way (Fig. 6). It is crucial to remark that the growthinhibitory action of $t c l y-b$ tomato digestate is active at a concentration much lower than that of purified $\beta$-carotene, although purified $\beta$-carotene was incorporated to a greater extent into the cells. Tomatoes contain several bioactive compounds, mainly lycopene but also other carotenoids such as $\beta$-carotene, phytoene, phytofluene, their metabolites and oxidative products, as well as vitamin $\mathrm{E}$, vitamin $\mathrm{C}$ and polyphenols ${ }^{(16)}$. $t l c y-b$ Tomatoes are enginereed to be very rich in $\beta$-carotene; however, as underlined above, other molecules, including a very small amount of lycopene, are present that are probably released by digestion and that can contribute in cooperation with $\beta$-carotene to the effects described.

It is also important to stress that micellarisation is a more physiological method to solubilise and deliver molecules, in particular lipophylic molecules, compared with the use of a solvent. In conclusion, the results obtained with this method point out that the whole digested food, containing different bioactive molecules at different relative concentrations, their metabolites, some minor components and the matrix itself, provides a unique mixture with a specific function in maintaining or protecting health.

In conclusion, simulated digestion is confirmed as a valid method to perform in vitro nutritional studies. The next crucial effort will be the analysis of the complete pattern of molecules involved in the effect observed and their interaction.

\section{Acknowledgements}

The present study was supported by the Ministry of Agriculture (MIPAF), 'GMO in Agriculture' and LYCOCARD, European Integrated Project no. 016213.

D. B. and P. P. performed most of the experiments and contributed equally to the discussion and to writing the manuscript; R. S. performed HPLC determinations; A. B. performed the cytofluorimetric assays; F. C. produced the tlcy- $b$ tomato and provided the homogenates; G. M., as coordinator of the project 'GMO in Agriculture', participated in the research planning and discussion of results; S. G. coordinated the research and contributed to the planning, realisation and discussion of the work.

P. P. and D. B. contributed equally to the present study. There is no conflict of interest that should be disclosed.

\section{References}

1. Nau H \& Blaner WS (1999) Retinoids: The Biochemical and Molecular Basis of Vitamin A and Retinoid. Action with Contributions by Numerous Experts. Handbook of Experiments Pharmacology, vol. 139 [H Nau and WS Blaner, editors] New York: Springer.

2. Blomhoff R \& Blomhoff HK (2006) Overview of retinoid metabolism and function. J Neurobiol 66, 606-630.

3. Sporn MB, Roberts AB \& Goodman DS (1994) The Retinoids: Biology, Chemistry and Medicine, 2nd ed. New York: Raven Press.

4. West KP Jr (2002) Extent of vitamin A deficiency among preschool children and women of reproductive age. J Nutr 132, 2857S-2866S.

5. Ye X, Al-Babili S, Kloti A, et al. (2000) Engineering the provitamin A ( $\beta$-carotene) biosynthetic pathway into (carotenoidfree) rice endosperm. Science 287, 303-305.

6. Diretto G, Al-Babili S, Tavazza R, et al. (2007) Metabolic engineering of potato carotenoid content through tuberspecific overexpression of a bacterial mini-pathway. PLoS ONE 2, e350.

7. Paine JA, Shipton CA, Chaggar S, et al. (2005) Improving the nutritional value of Golden Rice through increased pro-vitamin A content. Nat Biotechnol 23, 482-487.

8. D'Ambrosio C, Giorio G, Marino I, et al. (2004) Virtually complete conversion of lycopene into $\beta$-carotene in fruits of tomato plants transformed with the tomato lycopene $\beta$-cyclase $(t l c y-b)$ cDNA. Plant Sci 166, 207-214.

9. Krinsky NI \& Johnson EJ (2005) Carotenoid actions and their relation to health and disease. Mol Aspects Med 26, 459-516.

10. Stahl W \& Sies H (2005) Bioactivity and protective effects of natural carotenoids. Biochim Biophys Acta 1740, 101-107.

11. Bendich A \& Olson JA (1989) Biological actions of carotenoids. FASEB J 3, 1927-1932.

12. Giovannucci E (1999) Tomatoes, tomato-based products, lycopene, and cancer: review of the epidemiologic literature. J Natl Cancer Inst 91, 317-331.

13. Ranaldi G, Bellovino D, Palozza P, et al. (2007) Beneficial or detrimental effects of carotenoids contained in food: cell culture models. Mini Rev Med Chem 7, 1120-1128.

14. Palozza P, Serini S, Boninsegna A, et al. (2007) The growthinhibitory effects of tomatoes digested in vitro in colon adenocarcinoma cells occur through down regulation of cyclin D1, Bcl-2 and Bcl-xL. Br J Nutr 98, 789-795.

15. Campbell JK, Canene-Adams K, Lindshield BL, et al. (2004) Tomato phytochemicals and prostate cancer risk. J Nutr 134, 3486S-3492S.

16. Canene-Adams K, Campbell JK, Zaripheh S, et al. (2005) The tomato as a functional food. J Nutr 135, 1226-1230.

17. Garrett DA, Failla ML \& Sarama RJ (1999) Development of an in vitro digestion method to assess carotenoid bioavailability from meals. J Agric Food Chem 47, 4301-4309.

18. Jacobs DR Jr \& Tapsell LC (2007) Food, not nutrients, is the fundamental unit in nutrition. Nutr Rev 65, 439-450.

19. Hedren E, Diaz V \& Svanberg U (2002) Estimation of carotenoid accessibility from carrots determined by an in vitro digestion method. Eur J Clin Nutr 56, 425-430. 
20. Palozza P, Serini S, Torsello A, et al. (2003) Mechanism of activation of caspase cascade during $\beta$-carotene-induced apoptosis in human tumor cells. Nutr Cancer 47, 76-87.

21. Palozza P, Calviello G, Serini S, et al. (2001) $\beta$-Carotene at high concentrations induces apoptosis by enhancing oxy-radical production in human adenocarcinoma cells. Free Radic Biol Med 30, 1000-1007.

22. Willcox JK, Catignani GL \& Lazarus S (2003) Tomatoes and cardiovascular health. Crit Rev Food Sci Nutr 43, 1-18.

23. Sambuy Y, De Angelis I, Ranaldi G, et al. (2005) The Caco-2 cell line as a model of the intestinal barrier: influence of cell and culture-related factors on Caco- 2 cell functional characteristics. Cell Biol Toxicol 21, 1-26.

24. Parker SL, Tong T, Bolden S, et al. (1996) Cancer statistics, 1996. CA Cancer J Clin 46, 5-27.

25. Giovannucci E, Stampfer MJ, Colditz G, et al. (1992) Relationship of diet to risk of colorectal adenoma in men. $J$ Natl Cancer Inst 84, 91-98.

26. Mayne ST (1996) $\beta$-Carotene, carotenoids, and disease prevention in humans. FASEB $J \mathbf{1 0}, 690-701$.

27. Slattery ML, Benson J, Curtin K, et al. (2000) Carotenoids and colon cancer. Am J Clin Nutr 71, 575-582.

28. Anonymous (1994) The effect of vitamin $E$ and $\beta$ carotene on the incidence of lung cancer and other cancers in male smokers. The Alpha-Tocopherol, Beta Carotene Cancer Prevention Study Group. N Engl J Med 330, 1029-1035.

29. Greenberg ER, Baron JA, Tosteson TD, et al. (1994) A clinical trial of antioxidant vitamins to prevent colorectal adenoma. Polyp Prevention Study Group. N Engl J Med 331, 141-147.

30. MacLennan R, Macrae F, Bain C, et al. (1995) Randomized trial of intake of fat, fibre, and $\beta$ carotene to prevent colorectal adenomas. J Natl Cancer Inst 87, 1760-1766.

31. Taylor PR, Li B, Dawsey SM, et al. (1994) Prevention of esophageal cancer: the nutrition intervention trials in Linxian, China. Linxian Nutrition Intervention Trials Study Group. Cancer Res 54, 2029s-2031s.

32. Cahill RJ, O'Sullivan KR, Mathias PM, et al. (1993) Effects of vitamin antioxidant supplementation on cell kinetics of patients with adenomatous polyps. Gut 34, 963-967.

33. Alabaster O, Tang Z, Frost A, et al. (1995) Effect of $\beta$-carotene and wheat bran fibre on colonic aberrant crypt and tumor formation in rats exposed to azoxymethane and high dietary fat. Carcinogenesis 16, 127-132.

34. Tanaka T, Kawamori T, Ohnishi M, et al. (1995) Suppression of azoxymethane-induced rat colon carcinogenesis by dietary administration of naturally occurring xanthophylls astaxanthin and canthaxanthin during the postinitiation phase. Carcinogenesis 16, 2957-2963.

35. Palozza P, Maggiano N, Calviello G, et al. (1998) Canthaxanthin induces apoptosis in human cancer cell lines. Carcinogenesis 19, 373-376.

36. Palozza P, Calviello G, Maggiano N, et al. (2000) $\beta$-Carotene antagonizes the effects of EPA on cell growth and lipid peroxidation in WiDr adenocarcinoma cells. Free Radic Biol Med 28, 228-234.
37. Etcheverry P, Wallingford JC, Miller DD, et al. (2005) The effect of $\mathrm{Ca}$ salts, ascorbic acid and peptic $\mathrm{pH}$ on $\mathrm{Ca}, \mathrm{Zn}$ and $\mathrm{Fe}$ bioavailabilities from fortified human milk using an in vitro digestion/Caco-2 cell model. Int J Vitam Nutr Res 75, 171-178.

38. Cave NA (1988) Bioavailability of amino acids in plant feedstuffs determined by in vitro digestion, chick growth assay, and true amino acid availability methods. Poult Sci 67, 78-87.

39. Rao AV, Ray MR \& Rao LF (2006) Lycopene. Adv Food Nutr Res 51, 99-164.

40. Palozza P (2005) Can $\beta$-carotene regulate cell growth by a redox mechanism? An answer from cultured cells. Biochim Biophys Acta 1740, 215-221.

41. Palozza P, Serini S, Torsello A, et al. (2002) Regulation of cell cycle progression and apoptosis by $\beta$-carotene in undifferentiated and differentiated HL-60 leukemia cells: possible involvement of a redox mechanism. Int J Cancer 97, 593-600.

42. Bertram JS (2004) Induction of connexin 43 by carotenoids: functional consequences. Arch Biochem Biophys 430, 120-126.

43. Wertz K, Siler U \& Goralczyk R (2004) Lycopene: modes of action to promote prostate health. Arch Biochem Biophys 430, 127-134.

44. Balmer JE \& Blomhoff R (2002) Gene expression regulation by retinoic acid. J Lipid Res 43, 1773-1808.

45. Borel P, Grolier P, Armand M, et al. (1996) Carotenoids in biological emulsions: solubility, surface-to-core distribution, and release from lipid droplets. J Lipid Res 37, 250-261.

46. van Het Hof KH, West CE, Weststrate JA, et al. (2000) Dietary factors that affect the bioavailability of carotenoids. J Nutr $\mathbf{1 3 0}$, 503-506.

47. Korsmeyer SJ, Veis DJ, Merry DE, et al. (1993) Bcl-2/Bax: a rheostat that regulates an antioxidant pathway and cell death. Semin Cancer Biol 4, 327-332.

48. Palozza P, Serini S, Di Nicuolo F, et al. (2004) Modulation of apoptotic signalling by carotenoids in cancer cells. Arch Biochem Biophys 430, 104-109.

49. Kane DJ, Sarafian TA, Anton R, et al. (1993) Bcl-2 inhibition of neural death: decreased generation of reactive oxygen species. Science 262, 1274-1277.

50. Liu C, Lian F, Smith DE, et al. (2003) Lycopene supplementation inhibits lung squamous metaplasia and induces apoptosis via up-regulating insulin-like growth factor-binding protein 3 in cigarette smoke-exposed ferrets. Cancer Res 63, 3138-3144.

51. Palozza P, Serini S, Di Nicuolo F, et al. (2004) $\beta$-Carotene exacerbates DNA oxidative damage and modifies p53-related pathways of cell proliferation and apoptosis in cultured cells exposed to tobacco smoke condensate. Carcinogenesis 25, $1315-1325$

52. Sacha T, Zawada M, Hartwich J, et al. (2005) The effect of $\beta$-carotene and its derivatives on cytotoxicity, differentiation, proliferative potential and apoptosis on the three human acute leukemia cell lines: U-937, HL-60 and TF-1. Biochim Biophys Acta 1740, 206-214.

53. Bodzioch M, Dembinska-Kiec A, Hartwich J, et al. (2005) The microarray expression analysis identifies BAX as a mediator of $\beta$-carotene effects on apoptosis. Nutr Cancer 51, 226-235. 